\title{
Original article (full paper) \\ Effects of 22 weeks of training on functional markers and match performance of young soccer players
}

\author{
Rodrigo Leal de Queiroz Thomaz de Aquino \\ Universidade do Porto, Porto, Portugal \\ Luiz Guilherme Cruz Gonçalves \\ Lucas de Paula Oliveira \\ Hugo Tourinho Filho \\ Enrico Fuini Puggina \\ Universidade de São Paulo, Ribeirão Preto, SP, Brasil
}

\begin{abstract}
The aim of this study was to verify the effects of 22 weeks of training on functional markers and match performance through the use of earned points in competition. Twenty male soccer players were submitted to the same group of tests in four moments of the periodization: before the preparatory stage (T0); after the preparatory stage (T1); after the competitive stage I (T2); after the competitive stage II (T3). The functional markers were measured using the vertical and horizontal jump, T-40; Shuttle Run Test and RAST. The match performance was obtained by earned points in competition. An increase were found for all the variables analyzed for functional markers when T0 was compared with T3. In relation to the match performance, the team obtained $83.33 \%$ success in competitive stages. It is possible to conclude that training plan was efficient to improve technical-tactical skills and physical fitness of the studied athletes.
\end{abstract}

Keywords: periodization, motor skills, match performance, soccer

\section{Introduction}

The increasing professionalization and commercialization of sport followed by the growing investments has leading the athletes in searching of success to attract new investments (Gomes, 2009; Tourinho, 2001). However, high performance in sport implies in technological and scientific knowledge to prepare athletes according to their needs. Studies aiming to extend this knowledge to the annual training plan, called periodization, may contribute to the sports science based on practice, which may substitute the empiricism based on practice (Lopez, Marques, Tillaar, \& Gonzalez-Badillo, 2011).

Training periodization consists in establishing and guiding the athlete physical preparation process, in an attempt to achieve the best specific fitness in a target competition (Barbanti, 2010). Along with this, the physical fitness is understood as a biological adaptation process due to the training stimulus, manifested after a long-term preparation to the competition (Matvéiev \& Ruas, 1986). According to Borin, Gomes, \& Leite (2008), periodization is the process to unify the physical, technical, tactical and psychological variables that characterizes the athlete training to compete.

Currently, the periodization in soccer presents some difficulties. In the most part of the cases, the training is planed to immediate results, being directed to the team performance in just a part of the official matches. However, the player must acquire and maintain the physical fitness during annual cycles of training and competitions. Thus, the main objective of periodization in soccer is to reach the maximum level of performance aiming to succeed during the competitive season (Zakharov, 1992). Thus, one of the most common critics about the training programs for soccer players is that the competitive calendar does not allow to peak performance and to recover after the competitions (Sargentim, 2010).

Regarding to that, it was demonstrated that the team sports calendar, especially in soccer, are designed with an excess of matches in the competitions with very short periods to perform the pre season. Based on this statement, it was proposed the selective loads model of periodization, that consists in an annual cycle of 52 weeks, divided in two stages with 26 weeks each, characterizing a double periodization (Bompa, 2002; Gomes, 2009). The training load remains almost the same during the competition season, focusing on velocity performance. Thus, the proposition suggests that in the first training drive, the stimulations must be directed to the functional aspects of the body, alternating the emphasis to the neuromuscular training followed by velocity training.

In the model proposed by Gomes (2009) specific resistance, power manifestations (maximal power, fast power and endurance power), flexibility/coordination, technique and tactics and velocity are considered physical attributes of the athlete. The effectiveness of the model on functional markers were early investigated in basketball players (Moreira, 2006; Moreira, Okano, Souza, Oliveira, \& Gomes, 2005; Moreira, Oliveira, Ronque, Okano, \& Souza, 2008), soccer (Souza, 2006), and futsal (Thiengo et al., 2013). 
However, considering the training and competitive season of the players, as well the studies in providing scientific and practice knowledge in physical education and sport field, this study aimed to adapt the selective loads periodization model considering the execution and evaluation of the strategy verifying its efficacy. Thus, the original model proposed by Gomes (2009) consists in stimulate predominantly the technical and tactical capacities in all stages of the season. Considering that it is very important for the performance in the field. In other words, the functional and metabolic capacities of the players must be connected to the technical execution and tactical application of the game elements (Garganta, 2001). Based on that, the objective of this study was to investigate the effects of 22 weeks of training on functional markers and performance in the game in young soccer players.

\section{Methods}

\section{Participants}

Twenty male soccer players belonging to the under 17 category were selected to participate in the study. They have regularly trained and participated in the first division of professional league of the São Paulo state representing a club that they belong- Brazil.

For characterization of the participants, body composition (body mass, body fat, height), O2MAX and the peak height velocity were evaluated according to previous studies (Léger \& Lambert, 1982; Mirwald, Jones, Bailey, \& Beunen, 2002; Machado, Oikawa \& Barbanti, 2013). Data are summarized in Table 1.

Table 1. Sample characteristics expressed in mean \pm sd of age, height, body mass, body fat, peak height velocity and O2MAX.

\begin{tabular}{|c|c|}
\hline & Mean \pm SD \\
\hline Age (years) & $15.1 \pm 0.3$ \\
\hline Height $(\mathrm{cm})$ & $171.5 \pm 6.1$ \\
\hline Body Mass (kg) & $60.4 \pm 5.5$ \\
\hline Body Fat (\%) & $11.5 \pm 2.8$ \\
\hline Peak height velocity (years) & $1.42 \pm 0.5$ \\
\hline $\mathrm{O}_{2 \mathrm{MAX}}\left(\mathrm{ml} \cdot \mathrm{kg}^{-1} \cdot \mathrm{min}^{-1}\right)$ & $48.68 \pm 4.67$ \\
\hline
\end{tabular}

The participants were submitted to a periodization training program developed to improve the physical, technical and tactical components of soccer. The inclusion criteria were the participation in all of the sample collection and one uninterrupted year of soccer training.

The present study was approved by the ethics Commitee of the Ribeirão Preto Medical School of the University of São Paulo ( $\left.\mathrm{n}^{\circ} .710 .998\right)$. The participants and their legal responsible signed an informed consent and instructed about the procedures of the study.

\section{Overview of experimental design}

In this study, the periodization was consisted of 22 weeks, with 4 training sessions per week (Mondays, Tuesdays, Wednesdays and Thursdays), totalizing 96 training sessions of 100-120 minutes of duration, divided in three stages: preparatory stage (six weeks), competitive stage I (eight weeks) and competitive stage II (eight weeks). Ten official matches were performed during the target competition, divided into four in the competitive stage I and six in the competitive stage II. During the preparatory stage, two friendly matches were performed.

The subjects were evaluated in four moments: at beginning of the training season (TO), the end of the training season (T1), end of the competitive stage I (T2) and end of the competitive stage II (T3). The tests and retests to measure the functional markers were performed on the same time (approximately 05:30 PM) in the training field, always in the beginning of the week (Monday and Tuesday). The sequence of testing was standardized for the every moments of collection, starting with a standardized warm-up.

$1^{\circ}$ day of evaluation: afternoon-T-40 test (cyclic and acyclic velocity of displacement) and Running-based Anaerobic Sprint Test - RAST (anaerobic power).

$2^{\circ}$ day of evaluation: afternoon - vertical jump and horizontal jump from stand position (fast power) and Shuttle Run Test (aerobic power).

The soccer players performed a familiarization session with the tests one week before starting of the experimental protocol. The T-40 test, RAST, Shuttle Run Test were conducted on the grass field with soccer boots. The vertical and horizontal jump tests were performed inside the changing room with participants in barefoot.

\section{Determination of Displacement Speed Cyclic-Acyclic}

Aiming to evaluate the cyclic and acyclic velocity of displacement, T-40 test was applied to all participants (Moreira et al., 2005). The participant was positioned behind the start-stop line and started the test after the command. After the command, the volunteer ran $10 \mathrm{~m}$ straight to the first cone; after touching the hand in the cone of the center, quickly changed the direction to the left, toward the next cone positioned 5 meters from the center cone; after touch the left cone, the player returned to the previous direction, but moving to the cone on the right positioned 5 meters from the center cone, running 10 meters; after touching the right cone, the subject returned and touched the center cone and move toward to the start/stop cone, totalizing $40 \mathrm{~m}$ with four sudden stops, followed by changes of direction.

The time expend to perform the test was measured using a professional manual chronometer from TIMEX ${ }^{\circledR}$ (Waterburry, USA). Three attempts were done with two to three minutes rest between the attempts, considering the mean of the two best attempts. 


\section{Determination of Anaerobic Power}

To measure the aerobic power (fatigue index, minimum power, peak power and average power) of the players, the Running-based Anaerobic Sprint Test - RAST (Zacharogiannis, Paradisis, \& Tziortzis, 2004) was used. The athlete ran six times $35 \mathrm{~m}$ with ten seconds of passive rest between the sprints. The starts of the races were performed in the stop stand position and the time elapsed in each sprint was measured a professional manual chronometer from TIMEX $\AA$, as well as the interval between the sprints.

\section{Determination of Lower Limb Power}

Horizontal and vertical jump tests were used to assess the fast power of the power of the lower limbs. The vertical jump test was performed using the Ergojump System ${ }^{\circledR}$ (Bosco et al., 1995). The participants were instructed to perform the vertical jump using the countermovement technique. They were positioned in a stand position over the carpet with their feet parallel and hands on hips. It was not allowed to perform any movement with the arms when performing the jump, while the flexion and extension of the lower limbs were allowed (Smirniotou et al., 2008).

Horizontal jump test was also performed from the stand position. The subject started the attempt with his feet parallel and slightly apart, with toes behind the start line. After the command, the volunteer performed an arm swing and a semi flexion of the knees followed by jump itself aiming to reach the longest distance as possible from the starting line. The best attempt of vertical and horizontal jumps among three were considered for the further analysis (Moreira, Souza, \& Oliveira, 2003).

\section{Determination of $O 2 M A X$ and $V M A X$}

In order to access aerobic power of the participants, the Shuttle Run Test was performed (Léger \& Lambert, 1982). At the beep from an audio metronome, the participant started a $20 \mathrm{~m}$ running. After the first race, the athlete returned to the start line that should be reached exactly when the next beep was provided, running $40 \mathrm{~m}$ (scored as a stage). The test was started at $8,5 \mathrm{~km} / \mathrm{h}$, and the speed was increased in $1 \mathrm{~km} / \mathrm{h}$ at the end of each stage.

The time expend to cover the $40 \mathrm{~m}$ was progressively reduced. The aim of this test was to complete as many times as possible the distance of $40 \mathrm{~m}$ (completing the largest number of stages), finishing the test when the subject was not able to complete the stage two times or interrupted the test voluntarily. The last stage was computed for the O2MAX determination (Krustrup et al., 2006). The Kuipers, Verstappen, Keizer, Geurten, and Kranenburg (1985) equation was used to calculate the maximum intensity (VMAX) reached during the protocol as shown below:

$$
\mathrm{VMAX}=\mathrm{Ecom}+(\mathrm{t} / \mathrm{DE}) * \mathrm{I}
$$

Where "Ecom" represents the speed $(\mathrm{km} / \mathrm{h})$ in the last stage, " $\mathrm{t}$ " is the time (hours) elapsed in the last incomplete stage, "DE" means time (hours) of a complete stage and "I" is the intensity increment $(1 \mathrm{~km} / \mathrm{h})$.

\section{Training Program}

The specific game endurance was stimulated during the technical-tactical activities (small sided games) characterized by the use of the same rules of the sport with reduced field and number of players, and formal games (same rules of the game with maximum metabolic intensity) (Moreira, 2006). However, to ensure the development of aerobic power during the preparatory phase, the load of reduced and formal games was increased. The distribution of training content during the preparatory stage is shown in Table 2.

Table 2. Distribution of the training content among different capacities and skills during the preparatory stage.

\begin{tabular}{lcccccc}
\hline \multirow{2}{*}{ Training Content } & \multicolumn{7}{c}{ Distribution \% (weeks) } \\
\cline { 2 - 7 } & $\mathbf{1}$ & $\mathbf{2}$ & $\mathbf{3}$ & $\mathbf{4}$ & $\mathbf{5}$ & $\mathbf{6}$ \\
\hline Aerobic Power & 15 & 15 & 15 & 15 & 15 & 0 \\
Flexibility/Coordi- & 15 & 15 & 15 & 15 & 15 & 15 \\
nation & & & & & & \\
Strength & 20 & 20 & 20 & 20 & 20 & 25 \\
Velocity & 15 & 15 & 15 & 15 & 15 & 20 \\
Technique-Tactics & 35 & 35 & 35 & 35 & 35 & 40 \\
Stages & & \multicolumn{7}{c}{ Preparatory } \\
\hline
\end{tabular}

It is possible to observe that in the sixth week, the aerobic training load was interrupted due to the increase of technical-tactical training, considered intense to maintain the specific game endurance (Coelho et al., 2008; Impellizzeri et al., 2006). There was also an increase in strength and velocity training load.

The distribution of training loads during the competitive stage I and II are described in Table 3. It is observed in the competitive stage, the predominance of technical-tactical training and speed.

Table 3. Distribution of the training content among different capacities and skills during the competitive stage I and II.

\begin{tabular}{lcccc}
\hline \multirow{2}{*}{ Training Content } & \multicolumn{4}{c}{ Distribution \% (months) } \\
\cline { 2 - 5 } & $\mathbf{1}$ & $\mathbf{2}$ & $\mathbf{3}$ & $\mathbf{4}$ \\
\hline Aerobic Power & 0 & 0 & 0 & 0 \\
Flexibility/Coordination & 10 & 10 & 10 & 10 \\
Strength & 25 & 20 & 15 & 15 \\
Velocity & 20 & 25 & 25 & 25 \\
Technique-Tactics & 45 & 45 & 50 & 50 \\
Stages & Competitive I & Competitive II \\
\hline
\end{tabular}

Regarding the training load of the sessions, the training program was organized aiming to respect the progressive increase of stimulus principle of sports training (Moreira et al., 2005). 
Training load was measured by multiplying the total time expend to perform the training session by the perception of effort reported by the athletes at the end of training (Foster, 1998), given that it presents a strong correlation between heart rate and high applicability in athletes of collective sports as well as it is a simple, practical and inexpensive method (Impellizzeri, Rampinini, Coutts, Sassi, \& Marcora, 2004; Putlur et al., 2004). The dynamics of these variables (load and perceived exertion) along the timeline of this study is presented in Figure 1.

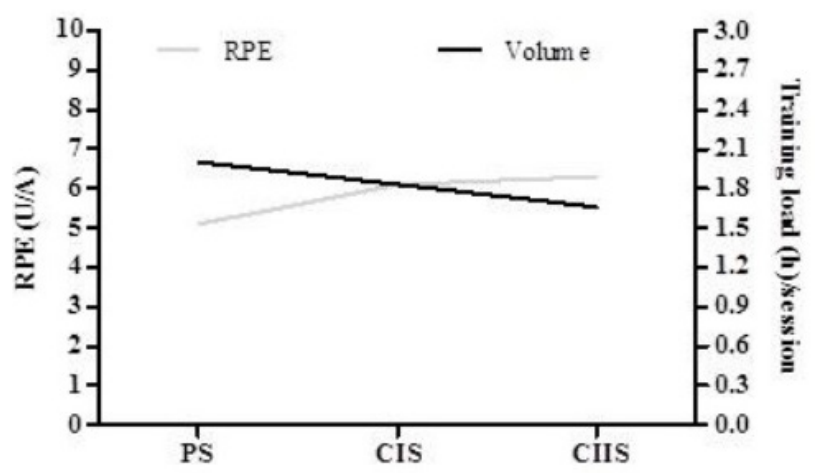

Figure 1. Training load (h) and ratings of perceived exertion (U/A) during the stages of periodization.

PS: Preparatory Stage; CIS: Competitive I Stage; CIIS: Competitive II Stage; RPE: Ratings of perceived exertion.

The training session to develop aerobic power during the preparatory stage in the $1 \mathrm{st}$ and 2 nd weeks was consisted of five series of three minutes at $90 \%$ of VMAX with 90 seconds of active recovery. The $3 \mathrm{rd}$, 4 th and 5 th weeks were consisted by three sets of five minutes at $95 \%$ of VMAX with 90 seconds of active rest. In the competitive stages, the aerobic training was replaced by increasing technical and tactical sessions, performed at high metabolic intensities. In the technical-tactical training sessions, the competition method was carried out aiming to increase the specificity of motor and cognitive-motor adaptations.

The coordinative exercises were used to improve the running technique in high speed, aiming to enable a specific economy of movement in soccer. Regarding flexibility, active stretching and ballistic exercises were performed. Maximum strength and power of lower limbs were stimulated with traction exercises followed by accelerations; jumps; pliometric exercises; active displacements (Tourinho, 2001). The cyclic-acyclic velocity of displacement was stimulated using maximum velocity sprints with and without changes of direction, and in an attempt to make the training sessions more specific, it was emphasized displacements belonging to the soccer game (front, back, side, diagonal) with $10 \mathrm{~s}$ of duration and a maximum of $30 \mathrm{~m}$ long (Sargentim, 2010).

\section{Statistical analysis}

The statistical analysis was performed using the Statistical Package for Social Sciences (SPSS) software for Windows ${ }^{\circledR}$, version 17.0. The distribution of the data was assessed by Shapiro-Wilk test and external functional markers in the four moments of collection (T0, T1, T2, T3) was tested by repetitive measurements ANOVA and when necessary followed by TukeyKramer post test. Performance in the field was characterized using descriptive statistics. The level of significance was set at $5 \%(p \leq 0.05)$.

\section{Results}

Figure 2 illustrates the cyclic-acyclic velocity of displacement dynamics on the four moments of collection. It was found significant differences in the comparisons among T0 with T2 ( $p$ $<0.001)$, T0 with T3 $(p<0.001)$, T1 with T2 $(p<0.001)$, T1 with T3 $(p<0.001)$ and T2 with T3 $(p=0.01)$. These results indicate that the training stimulus was not capable to promote increases in the T-40 test in the preparatory stage while in the competitive stages I and II was observed a significant increase.

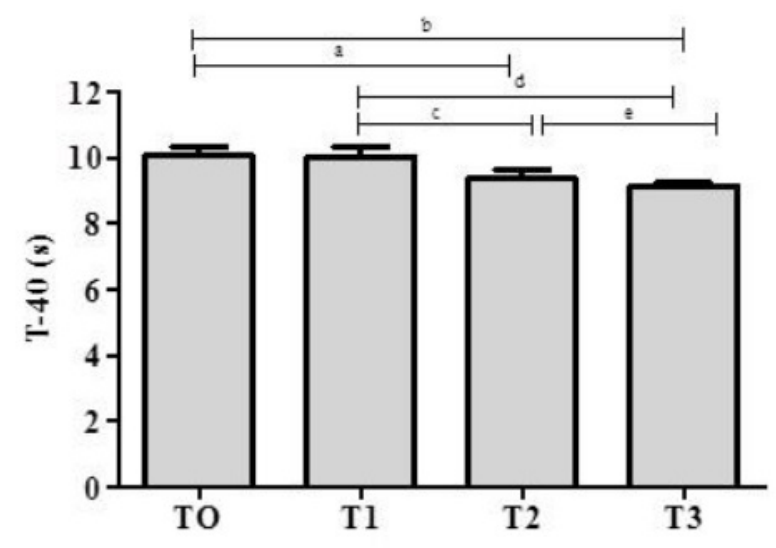

Figure 2. Cyclic-acyclic velocity displacement during the periodization.

$\mathrm{a}=\mathrm{T} 0 \times \mathrm{T} 2(p<0.001) ; \mathrm{b}=\mathrm{T} 0 \times \mathrm{T} 3(p<0.001) ; \mathrm{c}=\mathrm{T} 1 \times \mathrm{T} 2(p<0.001) ; \mathrm{d}$ $=\mathrm{T} 1 \times \mathrm{T} 3(p<0.001) ; \mathrm{e}=\mathrm{T} 2 \times \mathrm{T} 3(p=0.01)$.

Figure 3 shows the RAST test results (average power $-\mathrm{A}$; peak power $-\mathrm{B}$; minimum power $-\mathrm{C}$; fatigue index $-\mathrm{D})$. The average power was significantly increased when T0 was compared to T1, T2 and T3 $(p<0.001)$. However, no differences were found in the comparisons among T1 with T2, T1 with T3 and T2 with T3 $(p>0.05)$. Similar result was found for peak power.

Minimum power was improved when T0 was compared to $-\mathrm{T} 1, \mathrm{~T} 2, \mathrm{~T} 3(\mathrm{p}<0.001)$ and T1 with T2 $(p=0.04)$. In the comparisons among T1 to T3 and T2 with T3 no changes were found $(p>0.05)$. For the fatigue index, a difference was found only between T0 and T2 $(p=0.005)$ and T0 and T3 $(p=0.008)$.

In sum, in all variables obtained through the RAST, excepting the fatigue index, training sessions applied in the preparatory stage produced significant increases in the variables. Another important information is that the stimuli of competitive stage I and II were intense enough to maintain the performance levels acquired during the preparatory stage.

Regarding the performance in the horizontal jump (Figure 4 - A), there was significant difference in the comparison between T0 and T2 $(p=0.006)$, T0 and T3 $(p<0.001)$, T1 and T2 

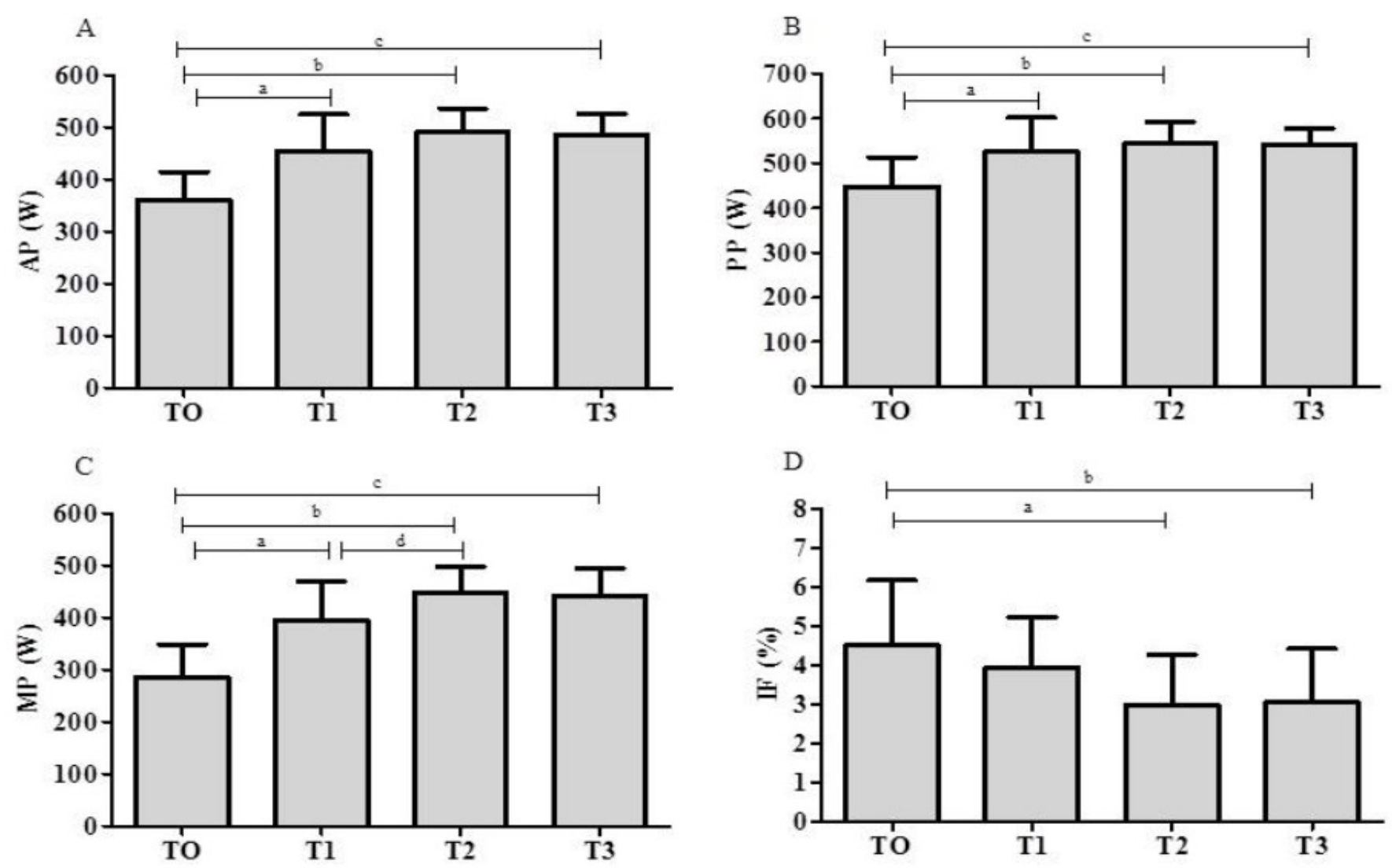

Figure 3. RAST test results.

Average Power (AP) - A, Peak Power (PP) - B, Minimium Power (MP) - C and Index of Fatigue (IF) - D during the periodization. A $-\mathrm{a}=\mathrm{T} 0 \mathrm{x}$ T1 $(p<0.001) ; \mathrm{b}$ $=\mathrm{T} 0 \times \mathrm{T} 2(p<0.001) ; \mathrm{c}=\mathrm{T} 0 \times \mathrm{T} 3(p<0.001) . \mathrm{B}-\mathrm{a}=\mathrm{T} 0 \times \mathrm{T} 1(p=0.001) ; \mathrm{b}=\mathrm{T} 0 \times \mathrm{T} 2(p<0.001) ; \mathrm{c}=\mathrm{T} 0 \times \mathrm{T} 3(p<0.001) . \mathrm{C}-\mathrm{a}=\mathrm{T} 0 \times \mathrm{T} 1(p<0.001) ; \mathrm{b}=\mathrm{T} 0$ x T2 $(p<0.001) ; \mathrm{c}=\mathrm{T} 0 \times \mathrm{T} 3(p<0.001) ; \mathrm{d}=\mathrm{T} 1 \times \mathrm{T} 2(p=0.04) . \mathrm{D}-\mathrm{a}=\mathrm{T} 0 \times \mathrm{T} 2(p=0.005) ; \mathrm{b}=\mathrm{T} 0 \times \mathrm{T} 3(p=0.008)$.

$(p=0: 02)$, T1 and T3 $(p<0.001)$ and T2 with T3 $(p<0.001)$. When comparing T0 with T1 collections, there was not significant difference $(p>0.05)$. The performance in the vertical jump (Figure 4 - B) showed similarities to the horizontal jump, obtaining significant difference $(p \leq 0.05)$, in all comparisons between the collections, except in the comparison between T0 with T1 $(p>0.05)$. Therefore, the stimuli offered during the preparatory phase were not able to significantly improve the performance in horizontal and vertical jump. However, during the competitive stage I and II, these variables were significantly increased.

Figure 5 illustrates the average values of O2MAX (A) and VMAX (B). Both variables revealed similar behavior for both indicators. There was a significant difference when T0 was
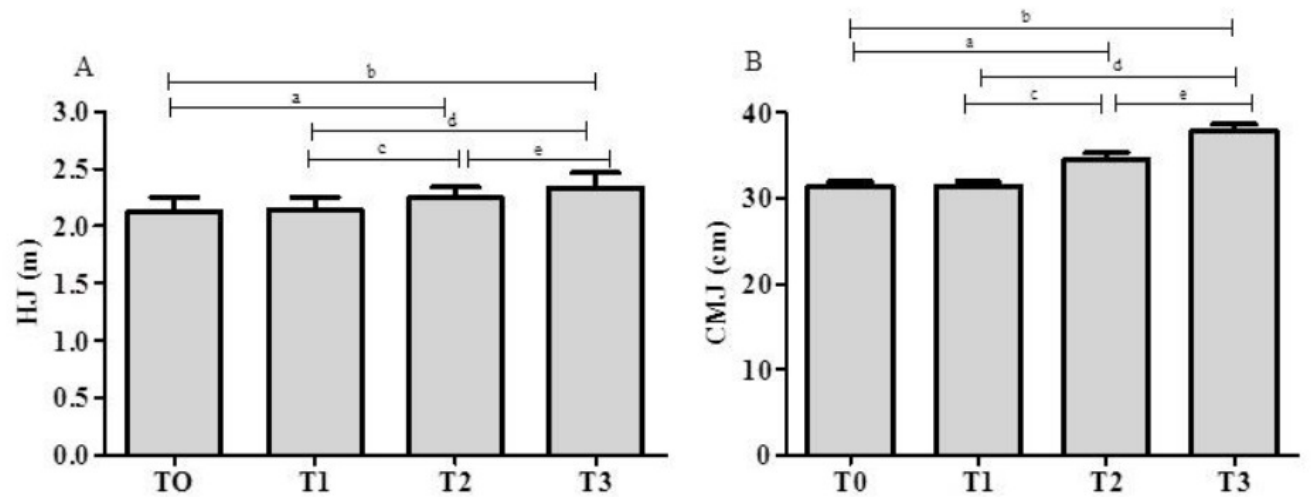

Figure 4. Performances in jumps.

Horizontal Jump (HJ) - A and Countermovement Jump (CMJ) - B tests during the periodization. $\mathrm{A}-\mathrm{a}=\mathrm{T} 0 \mathrm{x}$ T2 $(p=0.006) ; \mathrm{b}=\mathrm{T} 0 \mathrm{x}$ T3 $(p<0.001) ; \mathrm{c}=\mathrm{T} 1$ $\mathrm{x} 2(p=0.02) ; \mathrm{d}=\mathrm{T} 1 \times \mathrm{T} 3(p<0.001) ; \mathrm{e}=\mathrm{T} 2 \mathrm{x} \mathrm{T} 3(p<0.001) . \mathrm{B}-\mathrm{a}=\mathrm{T} 0 \mathrm{x} 2(p=0.01) ; \mathrm{b}=\mathrm{T} 0 \mathrm{x} 33(p<0.001) ; \mathrm{c}=\mathrm{T} 1 \mathrm{x} 2(p=0.04) ; \mathrm{d}=\mathrm{T} 1 \mathrm{x} \mathrm{T} 3(p<$ $0.001) ; \mathrm{e}=\mathrm{T} 2 \times \mathrm{T} 3(p=0.006)$. 
compared with the other collection times - T1, T2, T3 $(p<0.001)$. Therefore, it is possible to report that preparatory stage was efficient to promote improvements in O2MAX and VMAX. In addition, the competitive stages I and II were able to maintain the performance levels acquired during the preparatory phase.

The match performance analysis during the competition is described in Table 4.
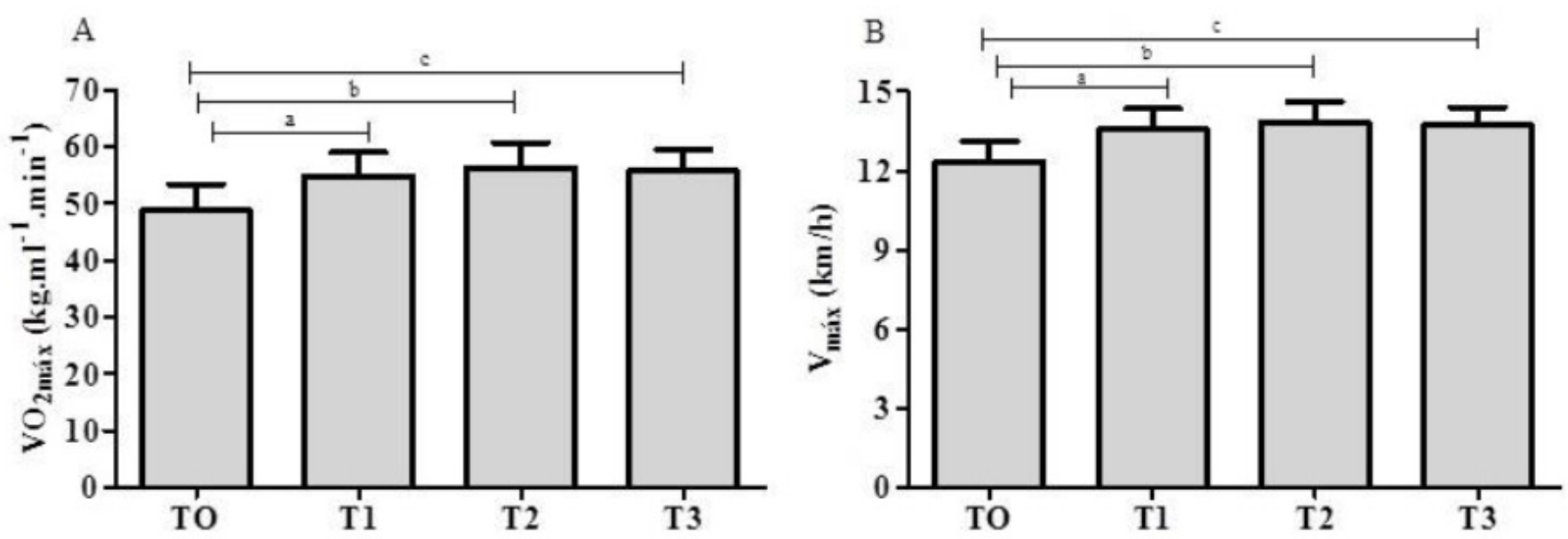

Figure 5. O2MAX and VMAX during the periodization.

$\mathrm{A}-\mathrm{a}=\mathrm{T} 0 \times \mathrm{T} 1(p<0.001) ; \mathrm{b}=\mathrm{T} 0 \times \mathrm{T} 2(p<0.001) ; \mathrm{c}=\mathrm{T} 0 \times \mathrm{T} 3(p<0.001) . \mathrm{B}-\mathrm{a}=\mathrm{T} 0 \times \mathrm{T} 1(p=0.001) ; \mathrm{b}=\mathrm{T} 0 \times \mathrm{T} 2(p<0.001) ; \mathrm{c}=\mathrm{T} 0 \times \mathrm{T} 3(p<0.001)$.

Table 4. Match performance in the competition during the stages of the periodization.

\begin{tabular}{lcc}
\hline & Competitive I Stage & $\begin{array}{l}\text { Competitive II } \\
\text { Stage }\end{array}$ \\
\hline $\mathrm{N}^{\circ}$ of Oficial Games & 4 & 6 \\
Disputed Points & 12 & 18 \\
Earned Points & 10 & 15 \\
Use of points (\%) & 83,33 & 83,33 \\
Placing & $2^{\circ}$ & $2^{\circ}$ \\
\hline
\end{tabular}

\section{Discussion}

The aim of the present study was to observe possible changes in the external markers resulting from an adaptation of the selective loads model and to examine the match performance of the young soccer players, in an attempt to optimize the development of motor and technical-tactical skills along the training program.

The results showed that the proposed periodization significantly affected performance in T-40 test, RAST, horizontal jump, vertical jump and Shuttle Run Test of young soccer players. Concomitantly, there was a satisfactory match performance during the competitive stages ( $83.33 \%$ games won), reaching the final stage and second position in the tournament. Accordingly, previous study analyzed the lower limbs power, acceleration and aerobic power during a macro cycle based on selective loads model in young soccer players of 18-20 years where it was found that eight weeks were not sufficient to promote any increase in this variable (Souza, 2006). However, for acceleration, the same author found significant change after eight weeks of training, which differs from the present study.
One possible explanation lies on the structural characteristics of the test used. In our study, it was used the T-40 test, which has rapid and constant changes of direction (cyclic-acyclic), being close to the soccer demands. In contrast, the previous study the analysis of the acceleration was carried out by a linear run of 40 meters (cyclic) (Souza, 2006). This difference in the results was also found by Moreira (2002).

Moreira et al. (2005) have demonstrated the effects of a preparatory stage composed by a five week meso cycle based on the selective loads model on lower limbs power and velocity in professional female basketball players. Using the T-40, vertical jumps (squat and countermovement), horizontal jump and unilateral triple horizontal jump (left and right legs), it was observed a significant increase in both variables, differently from our data, showing that these variables did change just after the competitive stage I. It is possible to attribute this difference to the training content used in the preparatory stage in our study, with emphasis on specific endurance (technical-tactical training), aerobic power and strength endurance. Other possible explanation is the fitness of the participants.

Thus, in the present study a trend in increasing cyclic-acyclic speed associated with the lower limbs power was found, showing a similarity of the behavior of these variables along with periodization. In agreement with our study, previous studies found this association (Driss, Vandewalle, \& Monod, 1998; Hennessy \& Kilty, 2001; Young, McLean, \& Ardagna, 1995).

The necessity imposed by soccer imposes a simultaneous training of the strength, endurance and velocity. Therefore, the improvement in one of these variables may affect the development of the other. Thus, the adaptive responses to training is specific to the stimulus offered and may cause an incompatibility 
between the adjustments, causing the "phenomenon of interference" (Hakkinen et al. 2003).

Although the training program of the present study have been proposed the simultaneous stimulus of the different capacities, it is possible to suggest that there was no negative interference of a capacity on the performance in the others. Accordingly, a previous study shows no effects simultaneous training on different capacities in futsal players (Tourinho, 2001).

Although there is need of aerobic in the beginning of the preparatory stage to support the development of other capacities during the periodization, in soccer there is also a need to improve strength (Nunez, Grigoletto, Castillo, Poblador, \& Lanc ho, 2008). Therefore, due to the age of the participants $(15.1 \pm 0.3$ years) and the short experience with strength training reported by the athletes, the periodization was used the maximum strength training during the preparatory stage (Gomes, 2009), and the endurance strength. Subsequently, in the competitive stages I and II, the training of power in the legs was conducted. Thus, due to structural characteristics of strength training used in this study, the significant changes in power of the lower limbs were found after 14 weeks of training.

Meylan and Malatesta (2009) verified the influence of a plyometric training program on power related actions of young soccer players (13.1 \pm 0.6 years). After eight weeks of training, the authors found increases in cyclic velocity, cyclic-acyclic velocity and power of the lower limbs, demonstrating the efficacy of the plyometric training to develop strength/velocity, corroborating with this study.

In relation to O2MAX and VMAX values, it was found a significant increase after the preparatory stage, occurring the maintenance of the values in competitive stages I and II. It is considered in this study that this maintenance was due to the increase of the training load of technical and tactical skills, stimulated by reduced and formal games. This result corroborates with studies reported in the literature that demonstrate the effectiveness of training programs composed by small sided games on physiological variables, mainly related to aerobic power (Hoff, Wisloff, Engen, Kemi, \& Helgerud, 2002; Impellizzeri et al., 2006; Owen, Wong del, Paul, \& Dellal, 2012).

Despite the predominance technical and tactical training over the other skills, which may have contributed to the match performance, it was feasible to significantly develop the external functional markers suggesting that the training organization was effective for the technical-tactical and physical improvement in the studied players.

In modern sport, mainly in collective sports, the training programs have been focused on motor skills, maybe under influence of sports physiology. However, it may not be useful to athlete excellent levels of functional markers whether they are not suitable to match situations. This reflection suggests a form of training that encompasses activities in the specific context of game, especially in sports training for young athletes (Pinho, Alves, Greco, \& Schild, 2010).

In this study, the periodization was proposed to develop the technical and tactical skills during the stages of the training program, concerning the cognitive processes related to perception, anticipation, decision making capacity and the indexes of strength and velocity.

In addition, a limitation of the present study was the use of T-40 test aiming to measure the agility capacity, since there are other motor tests already recognized and validated to verify this capacity in soccer players, as the Zig Zag Test (Little, \& Williams, 2005) eve though the test employed in our study has already been used in previous studies involving collective sports such as basketball, futsal and soccer (Moreira et al., 2005; Thiengo et al, 2013; Váczi, Tollár, Meszler, Juhász, \& Karsai, 2013).

We conclude that the periodization proposed in this study was effective in significantly raising the indices of the external markers, promoting a satisfactory performance when evaluated by scoring technical abilities along with competitive stages.

\section{References}

Barbanti, V.J. (2010). Treinamento esportivo: as capacidades motoras dos esportistas (1 ed.). Barueri: Manole.

Bompa, T.O. (2002). Periodização: teoria e metodologia do treinamento (4 ed.). São Paulo: Phorte.

Borin, J., Gomes, A., \& Leite, G.d.S. (2008). Preparação desportiva: aspectos do controle da carga de treinamento nos jogos coletivos. Revista da educação física/UEM, 18(1), 97-105. Retrieved from: http://www.periodicos.uem.br/ojs/index.php/RevEducFis/article/ view/3321

Bosco, C., Belli, A., Astrua, M., Tihanyi, J., Pozzo, R., Kellis, S., . . Tranquilli, C. (1995). A dynamometer for evaluation of dynamic muscle work. European Journal of Applied Physiology and Occupational Physiology, 70(5), 379-386. doi: 10.1007/ BF00618487

Coelho, D., Matos Rodrigues, de.V., Condessa, L.A., Mortimer, L.d.Á.C.F., Soares, D.D., \& Silami-Garcia, E. (2008). Intensidade de sessões de treinamento e jogos oficiais de futebol. Revista Brasileira de Educação Física e Esporte, 22(3), 211-218. Retrieved from: http://www.revistasusp.sibi.usp.br/pdf/rbefe/ v22n3/v22n3a05.pdf

Driss, T., Vandewalle, H., \& Monod, H. (1998). Maximal power and force-velocity relationships during cycling and cranking exercises in volleyball players. Correlation with the vertical jump test. Journal of Sports Medicine and Physical Fitness 38(4), 286-293. Retrieved from: http://europepmc.org/abstract/MED/9973770

Foster, C. (1998). Monitoring training in athletes with reference to overtraining syndrome. Medicine and science in sports and exercise, 30(7), 1164-1168. doi: 10.1097/00005768-199807000-00023

Garganta, J. (2001). A análise da performance nos jogos desportivos. Revisão acerca da análise do jogo. Revista Portuguesa de Ciências do Desporto, 1(1), 57-64. Retrieved from: http://observatorio.esportes.mg.gov.br/wp-content/uploads/2012/07/2001-A-an\%C3\%A1lise-da-performance-nosjogos-desportivos-Revis\%C3\%A3o-acerca-da-an\%C3\%A11ise-do-jogo-garganta.pdf

Gomes, A.C. (2009). Treinamento Desportivo: Estrututuração e Periodização (2ed.). Porto Alegre: Artmed. 
Hakkinen, K., Alen, M., Kraemer, W.J., Gorostiaga, E., Izquierdo, M., Rusko, H., .. . Paavolainen, L. (2003). Neuromuscular adaptations during concurrent strength and endurance training versus strength training. European Journal of Applied Physiology, 89(1), 42-52. doi: 10.1007/s00421-002-0751-9

Hennessy, L., \& Kilty, J. (2001). Relationship of the stretch-shortening cycle to sprint performance in trained female athletes. Journal of Strength and Conditioning Research, 15(3), 326-331. Retrieved from: http://journals.lww.com/nsca-jscr/pages/results. aspx?txtkeywords=Relationship + of + the + stretch-shortening + cycle+to + sprint + performance + in + trained + female + athletes .

Hoff, J., Wisloff, U., Engen, L.C., Kemi, O.J., \& Helgerud, J. (2002). Soccer specific aerobic endurance training. British Journal of Sports Medicine, 36(3), 218-221. Retrieved from: http://bjsm.bmj. com/content $/ 36 / 3 / 218$

Impellizzeri, F.M., Marcora, S.M., Castagna, C., Reilly, T., Sassi, A., Iaia, F.M., \& Rampinini, E. (2006). Physiological and performance effects of generic versus specific aerobic training in soccer players. International Journal of Sports Medicine, 27(6), 483-492. doi: $10.1055 / \mathrm{s}-2005-865839$

Impellizzeri, F.M., Rampinini, E., Coutts, A.J., Sassi, A., \& Marcora, S.M. (2004). Use of RPE-based training load in soccer. Medicine and Science in Sports and Exercise, 36(6), 1042-1047. Retrieved from: http://journals.lww.com/acsm-msse/pages/articleviewer. aspx .year $=2004 \&$ issue $=06000 \&$ article $=00018 \&$ type $=$ abstract

Krustrup, P., Mohr, M., Nybo, L., Jensen, J.M., Nielsen, J.J., \& Bangsbo, J. (2006). The Yo-Yo IR2 test: physiological response, reliability, and application to elite soccer. Medicine and Science in Sports and Exercise, 38(9), 1666-1673. doi: 10.1249/01. mss.0000227538.20799.08

Kuipers, H., Verstappen, F.T., Keizer, H.A., Geurten, P., \& Kranenburg, G. van, (1985). Variability of aerobic performance in the laboratory and its physiologic correlates. International Journal of Sports Medicine, 6(4), 197-201. doi: 10.1055/s-2008-1025839

Léger, L.A., \& Lambert, J. (1982). A maximal multistage 20-m shuttle run test to predict VO2 max. European Journal of Applied Physiology and Occupational Physiology, 49(1), 1-12. Retrieved from: http://download.springer.com/static/pdf/932/art\%253A10.1007\%252FBF00428958.pdf?auth66=1420575507_108db3fef49de319e0e417a804a81a03\&ext=. pdf

Little, T., Williams, A.G. (2005). Specificity of acceleration, maximum speed, and agility in professional soccer players. Journal of Strength and Conditioning Research, 19(1), 76-78.

Lopez-Segovia, M., Marques, M.C., Tillaar, R. van den, \& GonzalezBadillo, J.J. (2011). Relationships between vertical jump and full squat power outputs with sprint times in $\mathrm{u} 21$ soccer players. Journal of Human Kinetics, 30, 135-144. doi: 10.2478/v10078-011-0081-2

Machado, D., Oikawa, S., \& Barbanti, V. (2013). The multicomponent anthropometric model for assessing body composition in a male pediatric population: a simultaneous prediction of fat mass, bone mineral content, and lean soft tissue. Journal of Obesity, 2013, 428135. doi: 10.1155/2013/428135

Matvéiev, L., \& Ruas, M. (1986). Fundamentos do treino desportivo (1 ed.) Lisboa: Livros Horizontes.
Meylan, C., \& Malatesta, D. (2009). Effects of in-season plyometric training within soccer practice on explosive actions of young players. Journal of Strength and Conditioning Research, 23(9), 2605-2613. doi: 10.1519/JSC.0b013e3181b1f330

Mirwald, R.L., Baxter-Jones, A., Bailey, D.A., \& Beunen, G.P. (2002). An assessment of maturity from anthropometric measurements. Medicine and Science in Sports and Exercise, 34(4), 689-694. doi: 10.1097/00005768-200204000-00020

Moreira, A. (2002). Basquetebol: sistema de treinamento em bloco-organização e controle. (Mestrado), Universidade Estadual de Campinas, Campinas. Retrieved from: http://boletimef.org/ biblioteca/705/Basquetebol-sistema-de-treinamento-em-blocoorganizacao-e-controle

Moreira, A. (2006). A eficácia ea heterocronia das respostas de adaptação de basquetebolistas submetidos a diferentes modelos de estruturação da carga de treinamento e competição. . (Doutorado), Universidade Estadual de Campinas, Campinas. Retrieved from: http://www.nuteses.temp.ufu.br/tde_busca/arquivo.php?codArquivo $=6501 \&$ acordo $=$

Moreira, A., Okano, A.H., Souza, M., Oliveira, P.R., \& Gomes, A.C. (2005). Sistema de cargas seletivas no basquetebol durante um mesociclo de preparação: implicações sobre a velocidade e as diferentes manifestações de força. Revista Brasileira de Ciência e Movimento, 13(3), 7-16. Retrieved from: http://portalrevistas. ucb.br/index.php/RBCM/article/viewFile/639/650

Moreira, A., Oliveira, P.R., Ronque, E.R.V., Okano, A.H., \& Souza, M. (2008). Análise de diferentes modelos de estruturação da carga de treinamento e competição no desempenho de basquetebolistas no Yo-yo intermittent endurance test. Revista Brasileira de Ciências do Esporte, 29(2). Retrieved from: http://www.rbceonline.org.br/ revista/index.php/RBCE/article/view/124

Moreira, A., Souza, M., \& Oliveira, P.R. (2003). A velocidade de deslocamento no basquetebol. Revista Brasileira de Ciências do Esporte, 24(2). Retrieved from: http://rbceonline.org.br/revista/ index.php/RBCE/article/view/367

Nunez, V.M., Da Silva-Grigoletto, M.E., Castillo, E.F., Poblador, M.S., \& Lancho, J.L. (2008). Effects of training exercises for the development of strength and endurance in soccer. Journal of Strength and Conditioning Research, 22(2), 518-524. doi: 10.1519/ JSC.0b013e318163468f

Owen, A.L., Wong del, P., Paul, D., \& Dellal, A. (2012). Effects of a periodized small-sided game training intervention on physical performance in elite professional soccer. Journal of Strength and Conditioning Research, 26(10), 2748-2754. doi: 10.1519/ JSC.0b013e $318242 \mathrm{~d} 2 \mathrm{~d} 1$

Pinho, S.T., Alves, D.M., Greco, P.J., \& Schild, J.F.G. (2010). Método situacional e sua influência no conhecimento tático processual de escolares. Motriz, 16(3), 580-590. Retrieved from: http://www. scielo.br/pdf/motriz/v16n3/a05v16n3.pdf

Putlur, P., Foster, C., Miskowski, J.A., Kane, M.K., Burton, S.E., Scheett, T.P., \& McGuigan, M.R. (2004). Alteration of immune function in women collegiate soccer players and college students. Journal of Sports Science and Medicine, 3(4), 234-243. Retrieved from: http://www.ncbi.nlm.nih.gov/pmc/articles/PMC3938062/ pdf/jssm-03-234.pdf 
Sargentim, S. (2010). Treinamento de força no futebol (1 ed.) São Paulo: Phorte.

Smirniotou, A., Katsikas, C., Paradisis, G., Argeitaki, P., Zacharogiannis, E., \& Tziortzis, S. (2008). Strength-power parameters as predictors of sprinting performance. Journal of Sports Medicine and Physical Fitness 48(4), 447-454. Retrieved from: http://europepmc.org/ abstract/MED/18997647

Souza, E.N. (2006). Alterações das capacidades físicas de jovens futebolistas durante o macrociclo de treinamento: estudo a partir da periodização de cargas seletivas. (Mestrado), Universidade Metodista de Piracicaba, Piracicaba. Retrieved from: http://www. unimep.br/phpg/bibdig/pdfs/2006/GHKTCUYCMFWV.pdf

Thiengo, C.R., Talamoni, G.A., Silva, R.N.B.d., Morceli, H.d.S., Porfírio, J.C., Santos, J.W., \& Drigo, A.J. (2013). Effect of the periodization model with selective loads on motor abilities during a preparatory mesocycle in futsal players. Revista Brasileira de Ciências do Esporte, 35(4), 1035-1050. Retrieved from: http:// www.scielo.br/pdf/rbce/v35n4/15.pdf

Tourinho, H. Filho. (2001). Periodização de regimes de treinamentos antagônicos: um estudo sobre o futsal. (Doutorado), Universidade de São Paulo, São Paulo. Retrieved from: http://www.nuteses. temp.ufu.br/tde_busca/arquivo.php?codArquivo=5731\&acordo=

Váczi, M., Tollár, J., Meszler, B., Juhász, I., Karsai, I. (2013). Shortterm high intensity plyometric traning program improves strength, power and agility in male soccer players. Journal of Human Kinetics, 36, 17-21. Retrieved from: http://www.ncbi.nlm.nih.gov/ pmc/articles/PMC3661889/pdf/jhk-36-17.pdf

Young, W., McLean, B., \& Ardagna, J. (1995). Relationship between strength qualities and sprinting performance. Journal of Sports Medicine and Physical Fitness 35(1), 13-19. Retrieved from: http:// europepmc.org/abstract/MED/7474987

Zacharogiannis, E., Paradisis, G., \& Tziortzis, S. (2004). An evaluation of tests of anaerobic power and capacity. Medicine and Science in Sports and Exercise, 36(5), S116. doi: 10.1249/00005768-200405001-00549

Zakharov, A. (1992). Ciência do treinamento desportivo (1 ed.) Rio de Janeiro: Palestra Sport.

\section{Autor's note}

Rodrigo Leal de Queiroz Thomaz de Aquino is affiliated with University of Porto, Portugal. Luiz Guilherme Cruz Gonçalves, Lucas de Paula Oliveira, Hugo Tourinho Filho and Enrico Fuini Puggina are affiliated with University of São Paulo. Research group in Physical Performance and Sport Training.

\section{Acknowledgments}

CAPES (Coordenação de Aperfeiçoamento de Pessoal de Nível Superior) for the financial support.

\section{Corresponding author}

Enrico Fuini Puggina

Av. Bandeirantes, 3900, Monte Alegre, Ribeirão Preto, SP, Brazil.

Email: enrico@usp.br

Manuscript received on May 19, 2015

Manuscript accepted on January 24, 2016

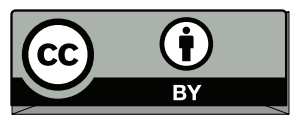

Motriz. The Journal of Physical Education. UNESP. Rio Claro, SP, Brazil - eISSN: 1980-6574 - under a license Creative Commons - Version 3.0 


\section{ERRATUM}

In the article " Effects of 22 weeks of training on functional markers and match performance of young soccer players", published in volume 22, number 2, 2016.

For characterization of the participants, body composition (body mass, body fat, height), O2MAX and the peak height velocity were evaluated according to previous studies (Léger \& Lambert, 1982; Mirwald, Jones, Bailey, \& Beunen, 2002; Machado, Oikawa \& Barbanti, 2013).

\section{Should read:}

For characterization of the participants, body composition (body mass, body fat, height), VO2max and the peak height velocity were evaluated according to previous studies (Léger \& Lambert, 1982; Mirwald, Jones, Bailey, \& Beunen, 2002; Machado, Oikawa \& Barbanti, 2013).

page 94, Methods

Table 1. Sample characteristics expressed in mean \pm sd of age, height, body mass, body fat, peak height velocity and O2MAX.

\begin{tabular}{cc}
\hline \multicolumn{3}{c}{ Mean \pm SD } \\
\hline Age (years) & $15.1 \pm 0.3$ \\
Height (cm) & $171.5 \pm 6.1$ \\
Body Mass (kg) & $60.4 \pm 5.5$ \\
Body Fat (\%) & $11.5 \pm 2.8$ \\
Peak height velocity (years) & $1.42 \pm 0.5$ \\
$\mathrm{O}_{2 \mathrm{MAX}}$ (ml.kg-1.min-1) & $48.68 \pm 4.67$ \\
\hline
\end{tabular}

\section{Should read:}

Table 1. Sample characteristics expressed in mean \pm sd of age, height, body mass, body fat, peak height velocity and VO2max.

\begin{tabular}{cc}
\hline \multicolumn{2}{c}{ Mean \pm SD } \\
\hline Age (years) & $15.1 \pm 0.3$ \\
Height (cm) & $171.5 \pm 6.1$ \\
Body Mass (kg) & $60.4 \pm 5.5$ \\
Body Fat (\%) & $11.5 \pm 2.8$ \\
Peak height velocity (years) & $1.42 \pm 0.5$ \\
$\mathrm{VO}_{2 \max }$ (ml.kg-1.min-1) & $48.68 \pm 4.67$ \\
\hline
\end{tabular}

page 94, Methods

\section{Determination of Anaerobic Power}

To measure the aerobic power (fatigue index, minimum power, peak power and average power) of the players, the Runningbased Anaerobic Sprint Test - RAST (Zacharogiannis, Paradisis, \& Tziortzis, 2004) was used.

\section{Should read:}


Determination of Anaerobic Power

To measure the anaerobic power (fatigue index, minimum power, peak power and average power) of the players, the Runningbased Anaerobic Sprint Test - RAST (Zacharogiannis, Paradisis, \& Tziortzis, 2004) was used.

page 95, Determination of Anaerobic Power

Determination of O2MAX and VMAX

Should read:

Determination of VO2max and Vmax

page 95, Determination of O2MAX and VMAX

The last stage was computed for the O2MAX determination (Krustrup et al., 2006). The Kuipers, Verstappen, Keizer, Geurten, and Kranenburg (1985) equation was used to calculate the maximum intensity (VMAX) reached during the protocol as shown below:

$\mathrm{VMAX}=\mathrm{Ecom}+(\mathrm{t} / \mathrm{DE}) * \mathrm{I}$

\section{Should read:}

The last stage was computed for the VO2max determination (Krustrup et al., 2006). The Kuipers, Verstappen, Keizer, Geurten, and Kranenburg (1985) equation was used to calculate the maximum intensity (Vmax) reached during the protocol as shown below:

$$
\operatorname{Vmax}=\mathrm{Ecom}+(\mathrm{t} / \mathrm{DE}) * \mathrm{I}
$$

page 95, Determination of O2MAX and VMAX

The training session to develop aerobic power during the preparatory stage in the 1 st and 2 nd weeks was consisted of five series of three minutes at $90 \%$ of VMAX with 90 seconds of active recovery. The $3 \mathrm{rd}$, 4th and 5 th weeks were consisted by three sets of five minutes at $95 \%$ of VMAX with 90 seconds of active rest.

\section{Should read:}

The training session to develop aerobic power during the preparatory stage in the 1st and 2nd weeks was consisted of five series of three minutes at $90 \%$ of Vmax with 90 seconds of active recovery. The 3rd, 4th and 5th weeks were consisted by three sets of five minutes at $95 \%$ of Vmax with 90 seconds of active rest.

page 96

Figure 3. RAST test results.

Average Power (AP) - A, Peak Power (PP) - B, Minimium Power (MP) - C and Index of Fatigue (IF) - D during the periodization. $\mathrm{A}-\mathrm{a}=\mathrm{T} 0 \times \mathrm{T} 1(p<0.001) ; \mathrm{b}=\mathrm{T} 0 \times \mathrm{T} 2(p<0.001) ; \mathrm{c}=\mathrm{T} 0 \times \mathrm{T} 3(p<0.001) . \mathrm{B}-\mathrm{a}=\mathrm{T} 0 \times \mathrm{T} 1(p=0.001) ; \mathrm{b}=\mathrm{T} 0 \times \mathrm{T} 2(p$ $<0.001) ; \mathrm{c}=\mathrm{T} 0 \times \mathrm{T} 3(p<0.001) . \mathrm{C}-\mathrm{a}=\mathrm{T} 0 \times \mathrm{T} 1(p<0.001) ; \mathrm{b}=\mathrm{T} 0 \times \mathrm{T} 2(p<0.001) ; \mathrm{c}=\mathrm{T} 0 \times \mathrm{T} 3(p<0.001) ; \mathrm{d}=\mathrm{T} 1 \times \mathrm{T} 2(p=$ $0.04)$. $\mathrm{D}-\mathrm{a}=\mathrm{T} 0 \times \mathrm{T} 2(p=0.005) ; \mathrm{b}=\mathrm{T} 0 \times \mathrm{T} 3(p=0.008)$. 


\section{Should read:}

Figure 3. Average Power (AP) - A, Peak Power (PP) - B, Minimium Power (MP) - C and Index of Fatigue (IF) - D during the periodization.

$\mathrm{A}-\mathrm{a}=\mathrm{T} 0 \times \mathrm{T} 1(p<0.001) ; \mathrm{b}=\mathrm{T} 0 \times \mathrm{T} 2(p<0.001) ; \mathrm{c}=\mathrm{T} 0 \times \mathrm{T} 3(p<0.001) . \mathrm{B}-\mathrm{a}=\mathrm{T} 0 \times \mathrm{T} 1(p=0.001) ; \mathrm{b}=\mathrm{T} 0 \times \mathrm{T} 2(p<$ $0.001) ; \mathrm{c}=\mathrm{T} 0 \times \mathrm{T} 3(p<0.001) . \mathrm{C}-\mathrm{a}=\mathrm{T} 0 \times \mathrm{T} 1(p<0.001) ; \mathrm{b}=\mathrm{T} 0 \times \mathrm{T} 2(p<0.001) ; \mathrm{c}=\mathrm{T} 0 \times \mathrm{T} 3(p<0.001) ; \mathrm{d}=\mathrm{T} 1 \times \mathrm{T} 2(p=$ $0.04) . \mathrm{D}-\mathrm{a}=\mathrm{T} 0 \times \mathrm{T} 2(p=0.005) ; \mathrm{b}=\mathrm{T} 0 \times \mathrm{T} 3(p=0.008)$.

page 97 , Figure 3

Figure 5 illustrates the average values of $\mathrm{O} 2 \mathrm{MAX}(\mathrm{A})$ and $\mathrm{VMAX}(\mathrm{B})$. Both variables revealed similar behavior for both indicators.

\section{Should read:}

Figure 5 illustrates the average values of $\mathrm{VO} 2 \mathrm{max}(\mathrm{A})$ and $\mathrm{Vmax}(\mathrm{B})$. Both variables revealed similar behavior for both indicators.

Figure 4. Performances in jumps.

Horizontal Jump (HJ) - A and Countermovement Jump (CMJ) - B tests during the periodization. A $-\mathrm{a}=\mathrm{T} 0 \times \mathrm{T} 2(p=0.006)$; $\mathrm{b}=\mathrm{T} 0 \times \mathrm{T} 3(p<0.001) ; \mathrm{c}=\mathrm{T} 1 \times \mathrm{T} 2(p=0.02) ; \mathrm{d}=\mathrm{T} 1 \times \mathrm{T} 3(p<0.001) ; \mathrm{e}=\mathrm{T} 2 \times \mathrm{T} 3(p<0.001) . \mathrm{B}-\mathrm{a}=\mathrm{T} 0 \times \mathrm{T} 2(p=0.01) ; \mathrm{b}=$ T0 × T3 $(p<0.001) ; \mathrm{c}=\mathrm{T} 1 \times \mathrm{T} 2(p=0.04) ; \mathrm{d}=\mathrm{T} 1 \times \mathrm{T} 3(p<0.001) ; \mathrm{e}=\mathrm{T} 2 \times \mathrm{T} 3(p=0.006)$.

\section{Should read:}

Figure 4. Horizontal Jump (HJ) - A and Countermovement Jump (CMJ) - B tests during the periodization.

$\mathrm{A}-\mathrm{a}=\mathrm{T} 0 \times \mathrm{T} 2(p=0.006) ; \mathrm{b}=\mathrm{T} 0 \times \mathrm{T} 3(p<0.001) ; \mathrm{c}=\mathrm{T} 1 \times \mathrm{T} 2(p=0.02) ; \mathrm{d}=\mathrm{T} 1 \times \mathrm{T} 3(p<0.001) ; \mathrm{e}=\mathrm{T} 2 \times \mathrm{T} 3(p<0.001)$. $\mathrm{B}-\mathrm{a}=\mathrm{T} 0 \times \mathrm{T} 2(p=0.01) ; \mathrm{b}=\mathrm{T} 0 \times \mathrm{T} 3(p<0.001) ; \mathrm{c}=\mathrm{T} 1 \times \mathrm{T} 2(p=0.04) ; \mathrm{d}=\mathrm{T} 1 \times \mathrm{T} 3(p<0.001) ; \mathrm{e}=\mathrm{T} 2 \times \mathrm{T} 3(p=0.006)$.

page 97 , Figure 4

Therefore, it is possible to report that preparatory stage was efficient to promote improvements in O2MAX and VMAX.

\section{Should read:}

Therefore, it is possible to report that preparatory stage was efficient to promote improvements in VO2max and Vmax.

Figure 5. O2MAX and VMAX during the periodization.

\section{Should read:}

Figure 5. VO2max and Vmax during the periodization. 
In relation to O2MAX and VMAX values, it was found a significant increase after the preparatory stage, occurring the maintenance of the values in competitive stages I and II.

\section{Should read:}

In relation to VO2max and Vmax values, it was found a significant increase after the preparatory stage, occurring the maintenance of the values in competitive stages I and II. 